\title{
Stream-Sediment Samples Reanalyzed for Major, Rare Earth, and Trace Elements from Ten 1:250,000-Scale Quadrangles, South-Central Alaska, 2007-08
}

Open-File Report 2010-1147 



\section{Stream-Sediment Samples Reanalyzed for Major, Rare Earth, and Trace Elements from Ten 1:250,000-Scale Quadrangles, South-Central Alaska, 2007-08}

By Elizabeth A. Bailey, Nora B. Shew, Keith A. Labay, Jeanine M. Schmidt,

Richard M. O'Leary, and David E. Detra

Open-File Report 2010-1147 


\title{
U.S. Department of the Interior \\ KEN SALAZAR, Secretary
}

\section{U.S. Geological Survey \\ Marcia K. McNutt, Director}

\section{U.S. Geological Survey, Reston, Virginia: 2010}

\begin{abstract}
For more information on the USGS — the Federal source for science about the Earth, its natural and living resources, natural hazards, and the environment, visit http://www.usgs.gov or call 1-888-ASK-USGS

For an overview of USGS information products, including maps, imagery, and publications, visit http://www.usgs.gov/pubprod

To order this and other USGS information products, visit http://store.usgs.gov
\end{abstract}

Any use of trade, product, or firm names is for descriptive purposes only and does not imply endorsement by the U.S. Government.

Although this report is in the public domain, permission must be secured from the individual copyright owners to reproduce any copyrighted materials contained within this report.

Suggested citation:

Bailey, E.A., Shew, N.B., Labay, K.A., Schmidt, J.M., O'Leary, R.M., and Detra, D.E., 2010, Stream-sediment samples reanalyzed for major, rare earth, and trace elements from ten 1:250,000-scale quadrangles, south-central Alaska, 2007-08: U.S. Geological Survey Open-File Report 2010-1147, 6 p. 


\section{Contents}

Abstract
Introduction.
Methods of Study
$\quad$ Sample Selection
$\quad$ Sample Preparation
Sample Analyses

\section{Figure}

Figure 1. Map showing location of 366 stream-sediment samples reanalyzed by the U.S. Geological Survey in the Anchorage, Bering Glacier, Big Delta, Gulkana, Healy, McCarthy, Mount Hayes, Nabesna, Talkeetna Mountains, and Valdez $1: 250,000$-scale quadrangles, Alaska .........................................

\section{Tables}

Table 1. Lower and upper reporting limits for 55 elements determined by ICP-AES and ICP-MS (sodium peroxide sinter decomposition)

Table 2. Major, rare earth, and trace element data for 366 stream-sediment samples originally collected by the U.S. Geological Survey in the Anchorage, Bering Glacier, Big Delta, Gulkana, Healy, McCarthy, Mount Hayes, Nabesna, Talkeetna Mountains, and Valdez 1:250,000-scale quadrangles, Alaska, 2007-08 http://pubs.usgs.gov/of20101147/ tab02.xls 


\section{Conversion Factors and Datum}

Inch/Pound to SI

\begin{tabular}{lll}
\hline \multicolumn{1}{c}{ Multiply } & By & \multicolumn{1}{c}{ To obtain } \\
\hline & Length & \\
inch (in.) & 2.54 & centimeter $(\mathrm{cm})$ \\
foot (ft) & 0.3048 & meter (m) \\
ounce, fluid (fl. oz) & 0.02957 & liter (L) \\
\hline
\end{tabular}

SI to Inch/Pound

\begin{tabular}{lcl}
\hline \multicolumn{1}{c}{ Multiply } & By & \multicolumn{1}{c}{ To obtain } \\
\hline & Length & \\
kilometer $(\mathrm{km})$ & 0.6214 & mile (mi) \\
milliliter & 0.0338 & ounce, fluid (fl. oz) \\
grams & 0.0353 & ounce, dry (U.S.) \\
\hline
\end{tabular}

Temperature in degrees Celsius $\left({ }^{\circ} \mathrm{C}\right)$ may be converted to degrees Fahrenheit $\left({ }^{\circ} \mathrm{F}\right)$ as follows:

$$
{ }^{\circ} \mathrm{F}=\left(1.8 x^{\circ} \mathrm{C}\right)+32 .
$$

Datum

Horizontal coordinate information is referenced to the North American Datum of 1983 (NAD 83). 


\title{
Stream-Sediment Samples Reanalyzed for Major, Rare Earth, and Trace Elements from Ten 1:250,000-Scale Quadrangles, South-Central Alaska, 2007-08
}

\author{
By Elizabeth A. Bailey, Nora B. Shew, Keith A. Labay, Jeanine M. Schmidt, Richard M. O'Leary, and David E. \\ Detra
}

\section{Abstract}

During the 1960s through the 1980s, the U.S. Geological Survey (USGS) conducted reconnaissance geochemical surveys of the drainage basins throughout most of the Anchorage, Bering Glacier, Big Delta, Gulkana, Healy, McCarthy, Mount Hayes, Nabesna, Talkeetna Mountains, and Valdez 1:250,000-scale quadrangles in Alaska as part of the Alaska Mineral Resource Assessment Program (AMRAP). These geochemical surveys provide data necessary to assess the potential for undiscovered mineral resources on public and other lands, and provide data that may be used to determine regional-scale element baselines. This report provides new data for 366 of the previously collected stream-sediment samples. These samples were selected for reanalysis because recently developed analytical methods can detect additional elements of interest and have lower detection limits than the methods used when these samples were originally analyzed. These samples were all analyzed for arsenic by hydride generation atomic absorption spectrometry (HGAAS), for gold, palladium, and platinum by inductively coupled plasma-mass spectrometry after lead button fire assay separation (FA/ICP-MS), and for a suite of 55 major, rare earth, and trace elements by inductively coupled plasmaatomic emission spectrometry and inductively coupled plasma-mass spectrometry (ICP-AES-MS) after sodium peroxide sinter at 450 degrees Celsius.

\section{Introduction}

During the 1960s through the 1980s, the U.S. Geological Survey (USGS) conducted reconnaissance geochemical surveys of the drainage basins throughout most of the Anchorage, Bering Glacier, Big Delta, Gulkana, Healy, McCarthy, Mount Hayes, Nabesna, Talkeetna Mountains, and
Valdez 1:250,000-scale quadrangles in Alaska as part of the Alaska Mineral Resource Assessment Program (AMRAP). More than 3,500 stream-sediment samples were collected in these 10 quadrangles in conjunction with the AMRAP studies.

In preparation for future mineral resource assessments, a percentage of these samples (about 10 percent) were selected for reanalysis because recently developed analytical methods can detect additional elements of interest and have lower detection limits than the methods used when the samples were originally analyzed. These samples were reanalyzed to determine if the original analyses are adequate for a regional-scale mineral resource assessment, to determine if the original data are adequate to establish regional-scale baselines for elements of interest, and to incorporate additional analyses of elements, such as platinum (Pt), palladium (Pd), and rare earth elements (REE).

\section{Methods of Study}

\section{Sample Selection}

Stream-sediment samples selected for reanalysis primarily were collected for the USGS Alaska Mineral Resource Assessment Program (AMRAP) during the 1960s-1980s. The sample details and previous analytical data can be found in reports listed in the section, "References Cited" This information also is stored digitally in the USGS National Geochemical Database (NGDB) (S.M. Smith, U.S. Geological Survey, oral commun., 2008) Samples to be reanalyzed were selected randomly from $10 \times 10 \mathrm{~km}$ $(6.2 \times 6.2 \mathrm{mi})$ grid cells that were overlaid on the study area to ensure a relatively even sample distribution. Sample materials remaining from the original analyses are stored in the USGS sample archive in Building 810 at the Denver Federal Center in Denver, Colo. A total of 366 samples (fig. 1) were selected and retrieved from the archive for reanalysis. 


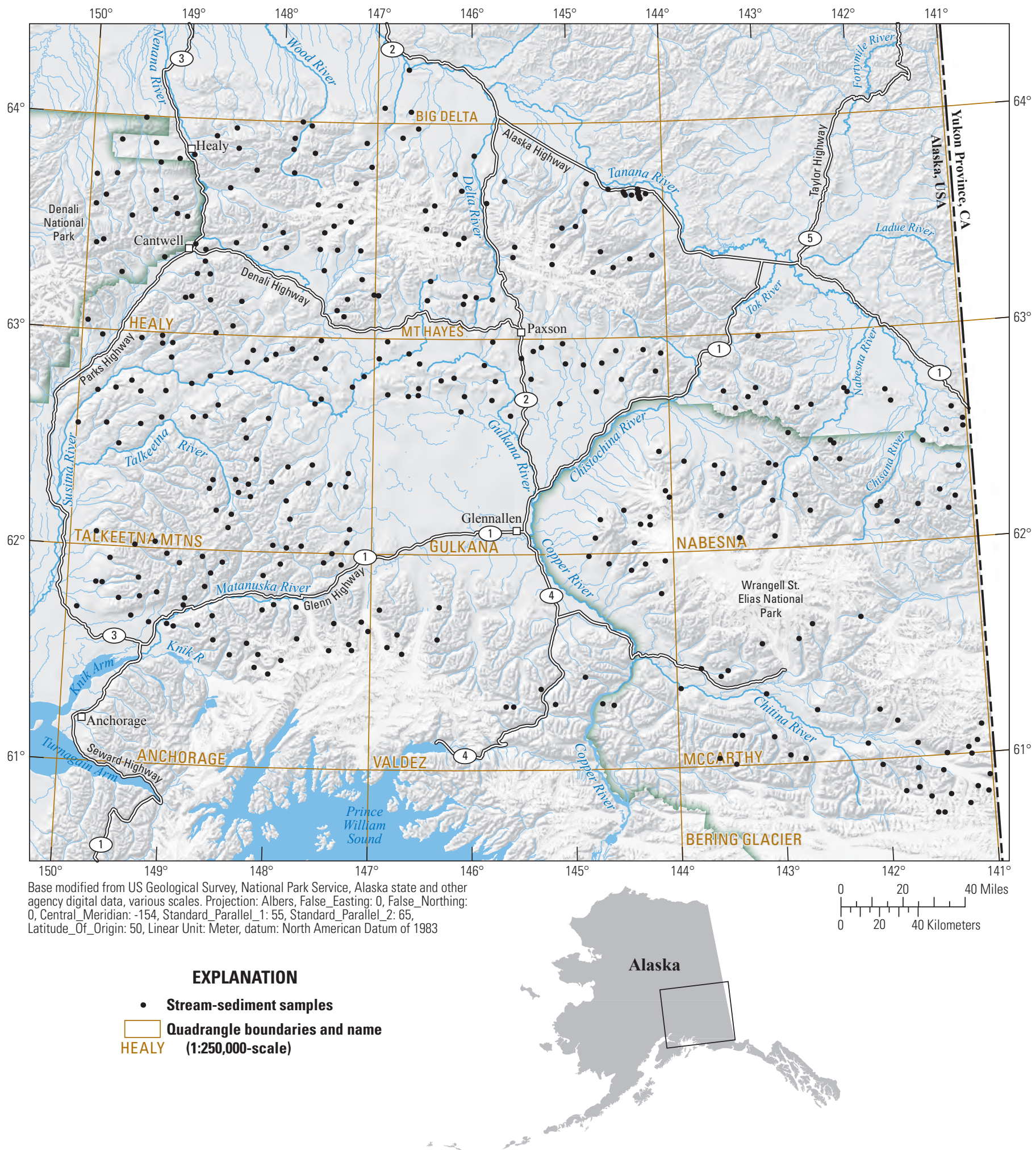

Figure 1. Location of 366 stream-sediment samples reanalyzed by the U.S. Geological Survey in the Anchorage, Bering Glacier, Big Delta, Gulkana, Healy, McCarthy, Mount Hayes, Nabesna, Talkeetna Mountains, and Valdez 1:250,000-scale quadrangles, Alaska. 
The original sample material collected consisted of finegrained active alluvium that was collected primarily from firstor second-order streams as shown on USGS 1:63,360-scale maps. Each sample was composited by collecting sediment increments from several places at the sample site, generally along a 30-ft stretch of the channel. Most samples were wet sieved on site into a 14-16 in. gold pan through a 10-mesh (2-mm) screen to remove pebbles.

\section{Sample Preparation}

When the samples originally were collected, they were either air-dried or oven-dried at less than $50{ }^{\circ} \mathrm{C}$ and then sieved with an 80 -mesh (less than $180-\mu \mathrm{m}$ ) screen. Sediment that passed through the sieve was ground in a vertical pulverizer with ceramic plates to 100 -mesh (less than $150-\mu \mathrm{m}$ ) (Peacock and others, 2002). Samples were prepared by USGS laboratories in Anchorage, Alaska, and Denver, Colorado.

\section{Sample Analyses}

The selected stream-sediment samples were analyzed for 55 major, rare earth, and trace elements by ICP-AES-MS (http://minerals.cr.usgs.gov/projects/analytical chem/ references.html\#m22; U.S. Geological Survey, 2010a) using a modification of Meier and Slowik (2002). Samples were decomposed by using a sodium peroxide sinter at $450{ }^{\circ} \mathrm{C}$. The resultant cake was leached with water and acidified with nitric acid. After an addition of tartaric acid, aliquots of the digested samples were aspirated into the ICP-AES and the ICP-MS. The concentrations of the optimal elements from the ICP-AES and ICP-MS were determined. Data were considered acceptable if recovery for all 55 elements was \pm 15 percent at five times the lower limit of detection (LOD) and the calculated relative standard deviation (RSD) of duplicate sample analysis was no greater than 15 percent. Lower and upper reporting limits for this method are shown in table 1.

Table 1. Lower and upper reporting limits for 55 elements determined by ICP-AES and ICP-MS (sodium peroxide sinter decomposition).

[ICP, inductively coupled plasma; AES, atomic emission spectrometry; MS, mass spectrometry; ppm, parts per million; \%, percent $]$

\begin{tabular}{|c|c|c|c|c|c|}
\hline \multirow{2}{*}{ Element } & \multicolumn{2}{|c|}{ Reporting limit } & \multirow{2}{*}{ Element } & \multicolumn{2}{|c|}{ Reporting limit } \\
\hline & Lower & Upper & & Lower & Upper \\
\hline Aluminum, $\mathrm{Al}$ & $0.01 \%$ & $25 \%$ & Lanthanum, La & $0.1 \mathrm{ppm}$ & $1 \%$ \\
\hline Calcium, $\mathrm{Ca}$ & $0.01 \%$ & $35 \%$ & Lead, $\mathrm{Pb}$ & 5 ppm & $1 \%$ \\
\hline Iron, $\mathrm{Fe}$ & $0.01 \%$ & $30 \%$ & Lithium, Li & $10 \mathrm{ppm}$ & $5 \%$ \\
\hline Potassium, K & $0.01 \%$ & $25 \%$ & Lutetium, Lu & $0.05 \mathrm{ppm}$ & $0.1 \%$ \\
\hline Magnesium, Mg & $0.01 \%$ & $30 \%$ & Molybdenum, Mo & $2 \mathrm{ppm}$ & $1 \%$ \\
\hline Manganese, Mn & $10 \mathrm{ppm}$ & $10 \%$ & Neodymium, $\mathrm{Nd}$ & $0.1 \mathrm{ppm}$ & $1 \%$ \\
\hline Phosphorous, P & $0.01 \%$ & $0.25 \%$ & Nickel, Ni & $5 \mathrm{ppm}$ & $1 \%$ \\
\hline Titanium, Ti & $0.01 \%$ & $25 \%$ & Niobium, $\mathrm{Nb}$ & $1 \mathrm{ppm}$ & $1 \%$ \\
\hline Silver, Ag & $1 \mathrm{ppm}$ & $0.1 \%$ & Praesodynium, Pr & $0.05 \mathrm{ppm}$ & $0.1 \%$ \\
\hline Arsenic, As & $30 \mathrm{ppm}$ & $10 \%$ & Rubidium, Rb & $0.2 \mathrm{ppm}$ & $1 \%$ \\
\hline Barium, Ba & $0.5 \mathrm{ppm}$ & $1 \%$ & Antimony, Sb & $0.1 \mathrm{ppm}$ & $500 \mathrm{ppm}$ \\
\hline Beryllium, Be & $5 \mathrm{ppm}$ & $0.25 \%$ & Scandium, Sc & $5 \mathrm{ppm}$ & $5 \%$ \\
\hline Bismuth, Bi & $0.1 \mathrm{ppm}$ & $0.1 \%$ & Samarium, Sm & $0.1 \mathrm{ppm}$ & $0.1 \%$ \\
\hline Cadmium, $\mathrm{Cd}$ & $0.2 \mathrm{ppm}$ & $1 \%$ & Tin, Sn & $1 \mathrm{ppm}$ & $1 \%$ \\
\hline Cerium, Ce & $0.1 \mathrm{ppm}$ & $1 \%$ & Strontium, Sr & $0.1 \mathrm{ppm}$ & $0.1 \%$ \\
\hline Cesium, Cs & $0.1 \mathrm{ppm}$ & $1 \%$ & Tantalum, Ta & $0.5 \mathrm{ppm}$ & $1 \%$ \\
\hline Chromium, $\mathrm{Cr}$ & $10 \mathrm{ppm}$ & $10 \%$ & Thallium, T1 & $0.5 \mathrm{ppm}$ & $0.1 \%$ \\
\hline Cobalt, Co & $0.5 \mathrm{ppm}$ & $1 \%$ & Thorium, Th & $0.1 \mathrm{ppm}$ & $0.1 \%$ \\
\hline Copper, $\mathrm{Cu}$ & $5 \mathrm{ppm}$ & $1 \%$ & Thulium, Tm & $0.05 \mathrm{ppm}$ & $0.1 \%$ \\
\hline Dysprosium, Dy & $0.05 \mathrm{ppm}$ & $0.1 \%$ & Tungsten, W & $1 \mathrm{ppm}$ & $1 \%$ \\
\hline Erbium, Er & $0.05 \mathrm{ppm}$ & $0.1 \%$ & Terbium, Tb & $0.05 \mathrm{ppm}$ & $0.1 \%$ \\
\hline Europium, Eu & $0.05 \mathrm{ppm}$ & $0.1 \%$ & Uranium, U & $0.05 \mathrm{ppm}$ & $0.1 \%$ \\
\hline Gadolinium, Gd & $0.05 \mathrm{ppm}$ & $0.1 \%$ & Vanadium, V & $5 \mathrm{ppm}$ & $1 \%$ \\
\hline Gallium, Ga & $1 \mathrm{ppm}$ & $0.1 \%$ & Ytterbium, Yb & $0.1 \mathrm{ppm}$ & $0.1 \%$ \\
\hline Germanium, Ge & $1 \mathrm{ppm}$ & $0.1 \%$ & Yttrium, Y & $0.5 \mathrm{ppm}$ & $1 \%$ \\
\hline Hafnium, Hf & $1 \mathrm{ppm}$ & $1 \%$ & Zinc, Zn & $5 \mathrm{ppm}$ & $1 \%$ \\
\hline Holmium, Ho & $0.05 \mathrm{ppm}$ & $0.1 \%$ & Zirconium, $\mathrm{Zr}$ & $0.5 \mathrm{ppm}$ & $1 \%$ \\
\hline Indium, In & $0.2 \mathrm{ppm}$ & $0.1 \%$ & & & \\
\hline
\end{tabular}


Gold (Au), Pt, and Pd concentrations were measured in the samples by ICP-MS after separation by lead button fire assay (http://minerals.cr.usgs.gov/projects/analytical chem/ references.html\#m20; U.S. Geological Survey, 2010b) using a modification of Meier and others (1996). An assay ton (30 g) was weighed into a crucible with $150 \mathrm{~g}$ of flux and mixed. One $\mathrm{mg}$ of silver nitrate was added and covered with borax, then placed in the furnace for $45 \mathrm{~min}$ at $1,080{ }^{\circ} \mathrm{C}$. The melt was poured into a cast iron mold, cooled, and hammered to free the lead button from the slag. The lead button was placed on a cupel and heated at $950{ }^{\circ} \mathrm{C}$ until all lead was removed. The resulting dore bead was dissolved in a mixture of nitric acid and hydrochloric acid and heated in a water bath. The final solution was adjusted to $10 \mathrm{~mL}$ and introduced into the ICP-MS. The lower reporting limits were $1 \mathrm{ppb}$ (part per billion) for $\mathrm{Au}, 1 \mathrm{ppb}$ for $\mathrm{Pt}$, and $0.5 \mathrm{ppb}$ for Pd. The upper reporting limit for all three elements was $10,000 \mathrm{ppb}$. Data were considered acceptable if recovery of $\mathrm{Au}, \mathrm{Pt}$, and $\mathrm{Pd}$ was \pm 20 percent at five times the lower reporting limit and the calculated percent RSD of duplicate samples was no greater than 20 percent.

Arsenic concentrations were determined by hydride generation-atomic absorption spectrometry (HGAAS) (http:// minerals.cr.usgs.gov/projects/analytical_chem/references. html\#M9; U.S. Geological Survey, 2010c); a method modified from Hageman and others (2002). An aliquot of sample $(0.1 \mathrm{~g})$ was weighed into a zirconium crucible. Approximately $0.75 \mathrm{~g}$ of sodium peroxide was added and mixed. The mixture was heated in a muffle furnace set at $750{ }^{\circ} \mathrm{C}$ for $4 \mathrm{~min}$. The sample was cooled, and then $15 \mathrm{~mL}$ of water and $5 \mathrm{~mL}$ of concentrated $\mathrm{HCl}$ were added. A $1 \mathrm{~mL}$ aliquot was shaken with $0.25 \mathrm{~mL}$ of an ascorbic acid/KI solution, then diluted to $10 \mathrm{~mL}$ with 20 percent $\mathrm{HCl}$ and allowed to stand overnight. The reporting range was $0.6-20 \mathrm{ppm}$. Data were considered acceptable if recovery of As was \pm 20 percent at five times the limit of detection (LOD) and the calculated percent RSD of duplicate samples is no greater than 20 percent.

Data for these stream-sediment samples are reported in table 2. All analyses were completed by laboratories under contract with the USGS.

\section{References Cited}

Arbogast, Belinda, Madden, Dawn, Hoffman, J.D., and O'Leary, R.M., 1987, Analytical results and sample locality map of stream-sediment, moraine-sediment, and heavy-mineral-concentrate samples from the Anchorage Quadrangle, south-central Alaska: U.S. Geological Survey Open-File Report 87-151, 175 p., 1 sheet, scale 1:250,000.
Clark, S.H.B., and Bartsch, S.R., 1971a, Reconnaissance geologic map and geochemical analyses of stream sediment and rock samples of the Anchorage B-6 Quadrangle, Alaska: U.S. Geological Survey Open-File Report 71-70, 63 p., 2 sheets, scale 1:63,360.

Clark, S.H.B., and Bartsch, S.R., 1971b, Reconnaissance geologic map and geochemical analyses of stream sediment and rock samples of the Anchorage B-7 Quadrangle, Alaska: U.S. Geological Survey Open-File Report 71-71, 70 p., 2 sheets, scale 1:63,360.

Folger, H.A., Koch, R.D., Hopkins, R.T., Cieutat, B.A., Goldfarb, R.J., Nokleberg, W.J., and Hoffman, J.D., 1995, Analytical results and sample locality maps of streamsediment, heavy-mineral-concentrate, and rock samples from the Gulkana Quadrangle, south-central Alaska: U.S. Geological Survey Open-File Report 95-509, 105 p., 2 sheets, scale 1:250,000.

George, S.L., 1995, Digital release of stream-sediment, heavy-mineral-concentrate, soil, and other geochemical data collected in the Nabesna $1 \mathrm{deg} \times 3 \mathrm{deg}$ Quadrangle, Alaska: U.S. Geological Survey Open-File Report 95-625, 10 p.

Goldfarb, R.J., Nelson, S.W., Dumoulin, J.A., Miller, M.L., Day, G.W., Hoffman, J.D., Tripp, Richard, Smaglik, Suzanne, and Folger, P.F., 1984, Data report and statistical summary for samples of moraine and stream sediment, nonmagnetic heavy-mineral concentrate and rocks from the Chugach National Forest, Alaska: U.S. Geological Survey Open-File Report 84-355, 446 p., 2 sheets, scale 1:250,000.

Hageman, P.L., Brown, Z.A., and Welsch, E., 2002, Arsenic and selenium by flow injection or continuous flow-hydride generation-atomic absorption spectrophotometry, in J.E. Taggart, Jr., ed., Analytical methods for chemical analysis of geologic and other materials, U.S. Geological Survey: U.S. Geological Survey, Open-File Report 2002-223-L, version 5.0, p. L1-L7, (available at http://pubs.usgs.gov/ of/2002/ofr-02-0223/L06AS24Se_M.pdf.)

Matson, N.A., Jr., and Richter, D.H., 1971a, Geochemical data from the Nabesna A-1 quadrangle, Alaska: U.S. Geological Survey Open-File Report 71-202, 10 p., 1 sheet, scale $1: 63,360$.

Matson, N.A., Jr., and Richter, D.H., 1971b, Geochemical data from the Nabesna C-4 quadrangle, Alaska: U.S. Geological Survey Open-File Report 71-203, 6 p., 1 sheet, scale $1: 63,360$.

Matson, N.A., Jr., and Richter, D.H., 1971c, Geochemical data from the Nabesna C-5 quadrangle, Alaska: U.S. Geological Survey Open-File Report 71-204, 10 p., 1 sheet, scale $1: 63,360$. 
Matson, N.A., Jr., and Richter, D.H., 1971d, Geochemical data from the Nabesna D-5 quadrangle, Alaska: U.S. Geological Survey Open-File Report 71-205, 8 p., 1 sheet, scale $1: 63,360$.

Matson, N.A., Jr., and Richter, D.H., 1972a, Additional geochemical data from the Nabesna C-4 and D-5 quadrangles, Alaska: U.S. Geological Survey Open-File Report 72-250, 5 p.

Matson, N.A., Jr., and Richter, D.H., 1972b, Geochemical data from the Nabesna B-3 quadrangle, Alaska: U.S. Geological Survey Open-File Report 72-251, 41 p., 1 sheet, scale $1: 63,360$.

Meier, A.L., Carlson, R.R., Lichte, F.E., and Bullock, J.H., 1996, Platinum group elements by nickel sulfide fire assay separation and inductively coupled plasma-mass spectrometry, in Arbogast., B.F., ed., Analytical methods manual for the Mineral Resource Surveys Program, U.S. Geological Survey: U.S. Geological Survey, Open-File Report 96-525, p. 158-165.

Meier, A.L. and Slowik, T., 2002, Rare earth elements by inductively coupled plasma-mass spectrometry, in Taggart, J.E., Jr., ed., Analytical methods for chemical analysis of geologic and other materials: U.S. Geological Survey: U.S. Geological Survey Open-File Report 2002-223-K, version 5.0, p. K1-K8, (available at http://pubs.usgs.gov/of/2002/ ofr-02-0223/K19NewREE_M.pdf.)

Miller, R.J., Curtin, G.C., Hopkins, R.T., Jr., and Csejtey, B., Jr., 1977, Spectrographic and chemical analyses of streamsediment and rock samples from the western part of the Talkeetna Mountains Quadrangle, Alaska: U.S. Geological Survey Open-File Report 77-471, 138 p., 2 sheets, scale 1:250,000.

Miller, R.J., Cooley, E.F., O’Leary, R.M., Garmezy, Larry, Csejtey, Bela, Jr., Smith, T.E., and Cleveland, M.N., 1978, Analysis of geochemical samples from the Talkeetna Mountains quadrangle, Alaska: U.S. Geological Survey Open-File Report 78-1052, 279 p.

Miller, R.J., Winkler, G.R., O’Leary, R.M., and Cooley, E.F., 1982, Analyses of rock, stream sediment, and heavy-mineral concentrate samples from the Valdez Quadrangle, Alaska: U.S. Geological Survey Open-File Report 82-451, 224 p., 2 sheets, scale 1:250,000.

O'Leary, R.M., McDanal, S.K., Day, G.W., McDougal, C.M., and Robinson, Keith, 1976, Spectrographic and chemical analyses of geochemical samples from the McCarthy Quadrangle, Alaska: U.S. Geological Survey Open-File Report 76-824, 806 p.
O’Leary, R.M., Cooley, E.F., Day, G.W., Hessin, T.D., McDougal, C.M., McDanal, S.K., and Clark, A.L., 1978, Spectrographic and chemical analyses of geochemical samples from the Big Delta Quadrangle, Alaska: U.S. Geological Survey Open-File Report 78-571, 127 p., 1 sheet, scale 1:250,000.

O’Leary, R.M., Risoli, D.A., Curtin, G.C., and McDanal, S.K., 1981, Spectrographic and chemical analyses of stream-sediment and glacial-debris samples from Mount Hayes Quadrangle, Alaska: U.S. Geological Survey Open-File Report 81-226, 55 p., 1 sheet, 1:250,000.

O'Leary, R.M., Risoli, D.A., Curtin, G.C., Tripp, R.B., McDougal, C.M., and Huston, D.L., 1982, Final analytical results of stream-sediments, glacial debris and nonmagnetic heavy-mineral concentrate samples from the Mt. Hayes Quadrangle, Alaska: U.S. Geological Survey Open-File Report 82-325, 128 p., 1 sheet, scale 1:250,000.

O’Leary, R.M., Hoffman, J.D., Sutley, S.J., and King, H.D., 1984, Analytical results and sample locality map of streamsediment and heavy-mineral-concentrate samples from the Healy Quadrangle, Alaska: U.S. Geological Survey OpenFile Report 84-104, 151 p., 1 sheet, scale 1:250,000.

Peacock, T.R., Taylor, C.D., and Theodorakos, P.M., 2002, Stream-sediment sample preparation, in Taggart, J.E., Jr., ed., Analytical methods for chemical analysis of geologic and other materials, U.S. Geological Survey: U.S. Geological Survey, Open-File Report 2002-223-A2, version 5.0, p. A2-1-A2-4 (available at http://pubs.usgs.gov/ of/2002/ofr-02-0223/A2SedPrep_M.pdf.)

Richter, D.H., and Matson, N.A., Jr., 1969a, Geochemical data from the Nabesna A-3 quadrangle, Alaska: U.S. Geological Survey Open-File Report 69-223, 6 p., 1 sheet, scale $1: 63,360$.

Richter, D.H., and Matson, N.A., Jr., 1969b, Geochemical data from the Nabesna B-4, quadrangle, Alaska: U.S. Geological Survey Open-File Report 69-224, 10 p., 1 sheet, scale $1: 63,360$.

Richter, D.H., and Matson, N.A., Jr., 1970a, Geochemical data from the Nabesna A-2 quadrangle, Alaska: U.S. Geological Survey Open-File Report 70-275, 7 p., 1 sheet, scale $1: 63,360$.

Richter, D.H., and Matson, N.A., Jr., 1970b, Geochemical data from the Nabesna A-4 quadrangle, Alaska: U.S. Geological Survey Open-File Report 70-276, 8 p., 1 sheet, scale $1: 63,360$. 
U.S. Geological Survey, 2010a, Method 22-55 element ICP-AES-MS sodium peroxide sinter, in USGS in-house methods: Central Mineral and Environmental Resources Science Center website, accessed May 21, 2010, at http:// minerals.cr.usgs.gov/projects/analytical chem/references. $\underline{\mathrm{html} \# \mathrm{~m} 22}$.

U.S. Geological Survey, 2010b, Methods 20-Gold, Platinum, and Palladium, in USGS in-house methods: Central Mineral and Environmental Resources Science Center website, accessed May 21, 2010, at http://minerals.cr.usgs.gov/ projects/analytical chem/references.html\#m20.
U.S. Geological Survey, 2010c, Methods $9 \& 11-$ Arsenic and Antimony, in USGS in-house methods: Central Mineral and Environmental Resources Science Center website, accessed May 21, 2010, at http://minerals.cr.usgs.gov/projects/ analytical chem/references.html\#M9. 
Publishing support provided by the U.S. Geological Survey

Publishing Network, Tacoma Publishing Service Center

For more information concerning the research in this report, contact the Director, Alaska Science Center

U.S. Geological Survey

4210 University Drive

Anchorage, Alaska 99508

http://alaska.usgs.gov 
品.

”

웋 